\title{
URBAN ENCOUNTERS: STASIS, MOVEMENT, EDITING AND MEMORY IN CONTEMPORARY CINEMA
}

\author{
Cecília Mello \\ Universidade Federal de São Paulo
}

\begin{abstract}
This article employs a comparative approach to connect cities and cinemas by discussing the presence of the urban space in the films Foreign Land (Terra Estrangeira, Walter Salles and Daniela Thomas, 1995), Head-On (Gegen die Wand, Fatih Akin, 2004), Import Export (Ulrich Seidl, 2007) and What Time Is It There? (Ni Neibian Jidian, Tsai Ming-liang, 2001). Shot mainly on location, these films are structured upon a movement between two cities, located in two different countries, and tackle questions of time and space and the fabrication of memory. A focus on their interconnectedness enables me to turn away from usual centre-periphery schemes and propose a new, and more complex, geography for recent and contemporary cinema.

Keywords: Cinema; Urban Spaces; Movement; Memory
\end{abstract}

A number of films made in the past twenty years across the world share a common ground in their privileged relation with the cities in

\begin{tabular}{|l|l|l|l|l|}
\hline Ilha do Desterro & Florianópolis & n 65 & p. 107- 134 & jul/dez 2013 \\
\hline
\end{tabular}


which they were filmed. By thinking of cinema as a spatial art, one which promotes a journey through different sites, this article employs a comparative approach to discuss the presence of the urban space in the films Foreign Land (Terra Estrangeira, Walter Salles and Daniela Thomas, 1995), Head-On (Gegen die Wand, Fatih Akin, 2004), Import Export (Ulrich Seidl, 2007) and What Time Is It There? (Ni Neibian Jidian, Tsai Ming-liang, 2001). These films have been chosen for they are structured upon a movement between two cities, located in two different countries, respectively São Paulo and Lisbon, Hamburg and Istanbul, Vienna and Snizhne, and Taipei and Paris. I endeavour to study how this movement promotes the cinematic encounter of two geographies, leading to questions connected to time and space and the fabrication of memory. As I will suggest, the memory of another space is unearthed in these films by a parallel editing structure which connects two different locations, as well as by other indexical cities within the profilmic event.

The four films under scrutiny are united by the prominent role assigned to the cities in which they were shot. Bringing together distant cities and cinemas in this analysis enables me to turn away from usual centre-periphery schemes and propose a new, and more complex, geography for recent and contemporary cinema. This approach has therefore a supranational quality, as it is not limited to a single city, a national cinema or a single director. Rather, it creates bridges between cinemas, interconnected by aspects of their representation or presentation of the urban space. It takes into account Lúcia Nagib’s "positive definition of world cinema" ("Towards"), which rejects the binary division between centre (Hollywood) and periphery (the rest of the world) by proposing a democratic and polycentric approach to the study of world cinema. This allows me to insert single films, without losing sight of their 
cultural specificities, in a new map, to be included in what Dudley Andrew has termed "An Atlas of World Cinema".

I will first present a brief theoretical discussion of the idea of cinema as a spatial art and discuss new concepts of (filmic) space that rebuff its equivalence with spatial representation. I will then introduce the films' basic narrative lines in order to show how they all replicate a similar structure, originating with the absence of movement or with death, travelling to another city in another country through a parallel editing structure and finally ending on the road, towards an unknown future. Finally, I will discuss how memory, usually associated in cinema with flashbacks and with the past, appears in these films as a spatial and present phenomenon, unearthed by the parallel editing technique.

\section{A Tale of Two Cities}

The relationship between cinema and the city has become a nodal point in Anglo-Saxon film theory from the mid-1990s onwards. In the words of Julia Hallam, it is "increasingly recognised as the archetypical ground for examining visual and sensory experience, form and style, perception, cognition and the meaning of the filmic image and filmic text" (277). Within the multiplicity of studies that have emerged in recent years, the writings of Giuliana Bruno stand out for their originality and their ground-breaking interdisciplinary approach. Her work expands on the sensorial quality of the cinematographic experience as identified by Gilles Deleuze, who signalled through his work in the 1980s a move from the optic to the haptic (1985). In her monumental Atlas of Emotion, Bruno draws on Sergei Eisenstein's essay "Montage and Architecture" (2010 [1938]) to suggest that cinema promotes a journey through different sites: 
Locked within a Lacanian gaze, whose spatial impact remained unexplored, the film spectator was turned into a voyeur. By contrast, when we speak of site-seeing we imply that, because of film's spatio-corporeal mobilization, the spectator is rather a voyageur, a passenger who traverses a haptic, emotive terrain. (Atlas 5-6)

By moving from optic to haptic, from voyeur to voyageur, the idea of cinema as a direct heir of Renaissance perspective is abandoned, and the appreciation of filmic space is considered from the point of view of touch and movement. Cinema, as proposed by Bruno, is an essentially spatial art, setting into motion an e-motional journey through multiple spaces. She evokes Michel de Certeau's well-known phrase "every story is a travel story-a spatial practice" to suggest that "film is the ultimate travel story. Film narratives generated by a place, and often shot on location, transport us to a site" ("City Views" 46). Film viewing is thus, in Bruno's terms, "an imaginary form of flânerie" (Atlas, 16).

In thinking of cinema as a spatial art, I take space to be defined by its dynamic characteristics and by movement, distinct from the idea of representation or of a static moment in time with which it is usually associated. Dorren Massey and Karen Lurey argue for a conceptualization of space that incorporates this principle when she writes that "no spaces are stable, given for all time; all spaces are transitory and one of the most crucial things about spatiality [...] is that it is always being made. The mobility of the cities is a hyperversion of spatiality in general" (231). Recent trends in urban geography indeed incorporate what has been termed the mobility paradigm, suggesting that "it is both possible and productive to interpret cities as organised through multiple forms of movement, rhythms and speeds" (Latham et al 33). This also points towards an understanding 
of the city not only as an isolated space but also as defined by its long distance relationships with other spaces, as for instance put forward by Saskia Sassen's definitive investigation of cross-border economic processes and her consequent conceptualisation of "the global city". Moreover, the city is increasingly understood not just as a physical structure but also as sites of meaning, experiences, exchanges and memories (Latham et al 11), a point to which I will return in the final part of this article.

If cities are a combination of structure and mobility, stasis and fluidity, cinema, the art of movement and a product of late nineteenthcentury modernity, seems to have a natural propensity for capturing the urban. Therefore, from the premise of the cinematographic experience as promoting a journey through spaces in movement, I endeavour to look at these urban films as spatial practices, departing from a real space and resulting in a new one, the filmic space, woven from urban sites and sounds, and through which one travels and feels. It is thus that the notion of movement becomes crucial to this investigation, a movement located between two cities, and which functions as a backwards and forwards drive, triggering in the travelling characters and in those left behind a series of impressions, emotions and memories, such stuff as urban spaces are made on.

\section{Foreign Land}

In Foreign Land, the city of São Paulo dialogues with Lisbon and indirectly with San Sebastián. Hailed as one of the first signs of Brazilian cinema's resurgence in the mid-1990s, Foreign Land echoes the postmodern cinema of citations of the 1980s, being openly indebted to works such as The Third Man by Carol Reed in its noirish sequences through the dark streets of Lisbon, as well as 
to Wim Wenders, Orson Welles, John Huston and Michelangelo Antonioni. Yet it also falls into a category of films which, in the words of Geoffrey Nowell-Smith, "yield up a sense of place that would have been impossible without the ontological link between nominal setting and actual location" (103). This means that the cities of São Paulo and Lisbon appear in the film as spaces that are intrinsically linked to the characters' frame of mind. Indeed it is no surprise to learn that, during the recce, different locations visited by directors Walter Salles and Daniela Thomas simply imposed themselves onto the film, with a definitive impact on the final script (2005).

The film starts in what would have been a joyful occasion in Brazilian recent history, had the democratically-elected president Fernando Collor de Mello been the redemptive promise some hoped him to be by bringing 25 years of military dictatorship to an end in 1990. Instead, one of the first measures of what turned out to be his short-lived administration was the freezing of all bank accounts across the country, as part of an ill-fated economic plan aimed at putting an end to inflation. The 1990s then turned out to be the decade in which Brazil, traditionally a country of immigration, became a country of emigration, as many fled for greener pastures, hoping for an economically safer future.

Paco lives with his mother Manuela in São Paulo, in a small flat facing a viaduct whose static image opens the film. Originally from San Sebastián in the Basque country, Manuela nurtures a wish to travel back to her homeland, which she-as countless other immigrants which make up Brazil's social tapestry-had left many decades before. On hearing the news of the freezing of bank accounts she realises that her dream of returning home is jeopardised, has a heart attack and dies. Paco, faced with the sudden loss of his mother, rummages through her pictures and postcards as if trying to make 
sense of his own identity. Later he goes to a bar and drowns his sorrows while holding a postcard of San Sebastián in his hands. There he will meet a Mephistophelian character named Igor, who proposes a pact through which a trip to Lisbon will be paid for in exchange for the delivery of a violin.

So far the images of São Paulo reveal a grim and grey city, much in tune with Paco's grief. The very immobility of the viaduct, complemented by an underwear advert ironically called Hope, seems to be a reflection of the character's stagnation. Paco is after all a physics student who aspires to become an actor, but who fails to speak during his audition to the part of Faust, which, as Carolin Ferreira points out, will be "assigned to Paco by reality" (734). Nicknamed the "big worm", the viaduct is a defining feature of São Paulo's urban decay, seen unanimously as an aberration and a brutality, built in the late 1960s by a corrupt mayor appointed by the military regime. Its image becomes particularly symbolic in the aftermath of Manuela's death, standing for her "heart which ceased to beat", in the directors' words (Salles/Thomas 2005). The film thus starts with the stasis which precedes movement: the broken lift in the flat, which has Manuela complaining about having to climb the stairs; the freezing of bank accounts; the inability to speak; and ultimately death. The "big worm" defines São Paulo and finds an echo in the immobility of the shipwreck encountered by Paco and Alex, a Brazilian émigré living in Lisbon, towards the end of the film. Stasis, though, contains in itself the suggestion of mobility, for the opening shots of the viaduct are accompanied by Paco's rehearsal to the part of Faust, in which he repeats the verses "I feel the courage, the impulse to go forth into the world", and "I want the whole of life", as if in anticipation of the journey he will undertake. 
114 Cecília Mello, Urban Encounters: Stasis, Movement, Editing and ...

Across the ocean, Foreign Land first sees and hears Lisbon through the tourist eye, with images of boats sailing the Tagus enhanced by a fado, the traditional Portuguese music, only here a piece composed by Brazilian musician José Miguel Wisnik. The film, shot in black and white, seems to be "more black" than white in São Paulo, and "more white" than black in Lisbon, whose nickname is indeed "The White City". During the first forty minutes, it employs a parallel editing structure, moving backwards and forwards from one city to the other fourteen times, with sequences varying from a steady length of six minutes to increasingly shorter ones. Each cut has a precise visual or narrative cue, so the first reference to San Sebastián motivates the first cut to Lisbon ${ }^{1}$, and Alex's confession of fearing one day having to return to Brazil is followed by the dreadful "big worm", wrecked in the urban space. The editing also seems to mimic the stasis/mobility tension established in the first shot, gaining momentum and finally embracing the conventions of the thriller genre once it leaves Brazil for good, following Paco on his way to the motherland. In Lisbon, he will encounter Alex and her boyfriend Miguel, the addressee of the mysterious violin. It is suggested that both had left Brazil in search of a better life, but while one waits tables the other nurtures a failed career as musician and heavy drug habit.

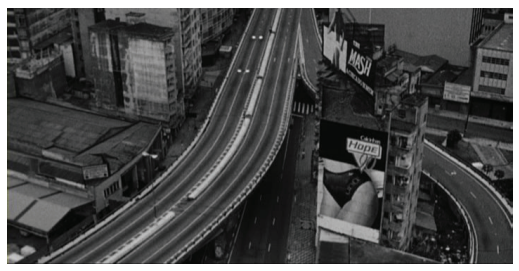

The "big worm" in São Paulo

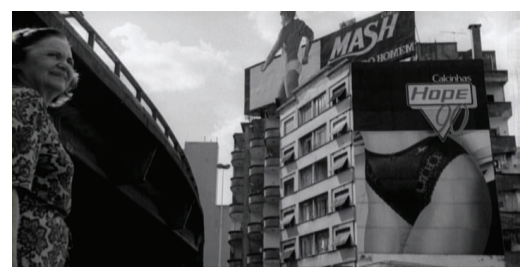

Manuela and the "Hope" advert 

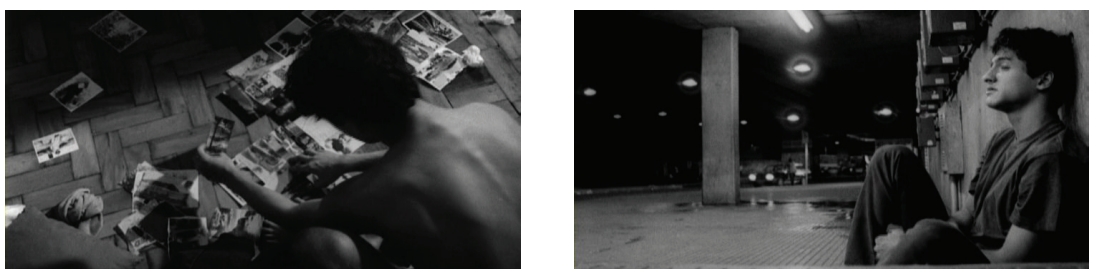

Paco tries to piece together his co's grief

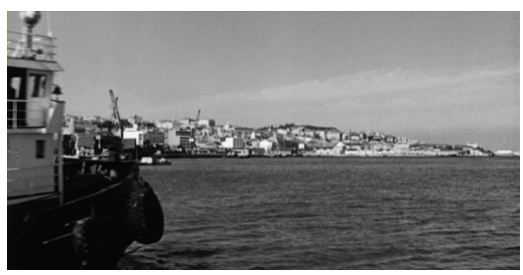

First shot of Lisbon and the Tagus
A grim urban space in tune with $\mathrm{Pa}$ mother's past

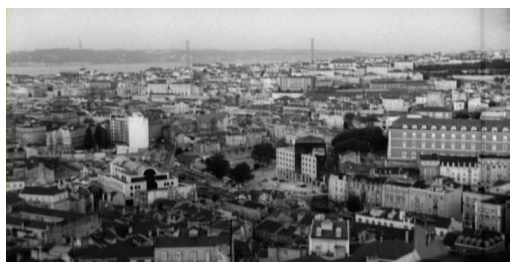

Lisbon, the so-called "white city"

\section{Head-On}

Fatih Akin's Head-On also begins with stasis: Cahit, a German citizen of Turkish origin living in Hamburg, drives his car against a wall in a suicide attempt, to the sound of Depeche Mode's "I Feel You"-a song not surprisingly written by David Gahan during his suicidal period. Yet the song also has a premonitory stance in the chorus "this is the dawning of our love", for Cahit, a widower who works in a nightclub collecting empties, and who struggles with painful memories of his late wife, will soon meet Sibel. She is like him a German citizen of Turkish origin, and their meeting happens inside the hospital where she is also recovering from a suicide attempt. The end of the road and the death drive are by and large associated with the end of narrative, yet here they become the impetus of a new start: the couple engage through a marriage of convenience but end up 
falling in love. Following a tragic event in which Cahit kills one of Sibel's lovers, they become estranged and she leaves Hamburg for Istanbul. After years in prison, Cahit takes the same journey in an attempt to re-connect with his love.

Head-On is the fourth feature of German director Fatih Akin, who was born in Hamburg and shares with his characters the Turkish background. At least two thirds of the film take place in the German city, in internal and external locations well-known to the director in and around the Altona Borough. These locations reveal an environment filled with Turkish elements such as shops and restaurants, as well as the Taksim nightclub which plays Turkish pop music, integrated in the film's soundtrack with the post-punk sounds of Depeche Mode, The Birthday Party and The Sisters of Mercy. Yet Istanbul is there from the beginning, in shots of a band performing traditional Turkish music on the banks of the Golden Horn, with a postcard image of the city in the background. The songs played allude to issues of love, loss, distance and nostalgia, well in tune with Cahit and Sibel's painful existence. This image sets in motion the tableau structure of the film, which travels backwards and forwards between the two cities five times.
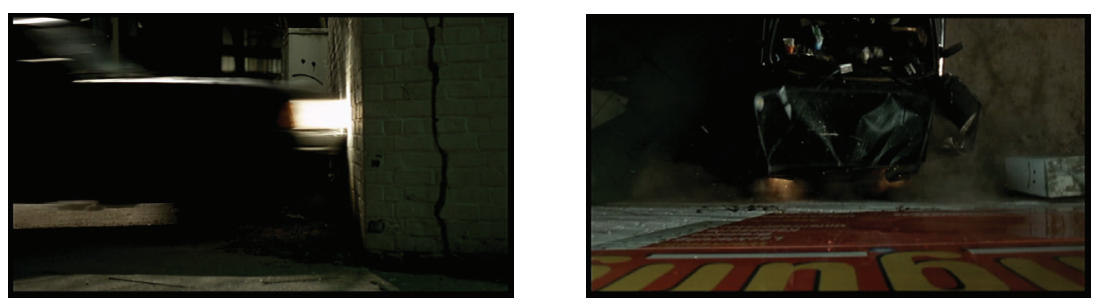

Cahit drives his car against a wall in Fatih Akin's Head-On 

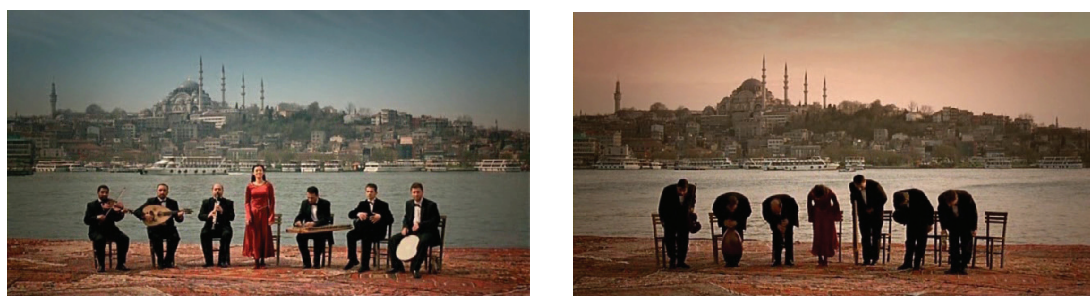

A "postcard image" of Istanbul marks the film's tableau structure

Both Foreign Land and Head-On, regardless of crucial differences concerning the issue of identity, present the journey to a new city as the wish and the possibility to start anew, following painful memories connected to the experience of loss and death: images of the airplane, of the arrival at the airport and at the Grand Hotel de Londres in Istanbul, as well as scenes which take place in locations overlooking the urban landscape, find resonance in Foreign Land, where Paco is seen arriving at the airport, staying in a similarly charming old hotel overlooking the water, and where Alex and Miguel admire Lisbon from a vantage point. It is also noticeable how both São Paulo and Hamburg were deprived of cityscape shots, receiving a more fragmented and internalized treatment that seems to be the product of the directors' "internal point of view", or at least their increased familiarity with their own environment. On the contrary, Lisbon and Istanbul appear more than once from vantage points, in all their glory.

Finally, both films end on the road, but in a movement yet again marred by death and loss. In Foreign Land Alex and Paco flee towards San Sebastián, driving illegally across the Spanish border on a country road. But Paco has just been shot by a gang of diamond smugglers, and is dying on Alex's lap. In Head-On, Cahit boards a coach, but Sibel, who had promised to join him, realises she cannot 
118 Cecília Mello, Urban Encounters: Stasis, Movement, Editing and ...

abandon the life of stability she had finally found after years of selfdestruction and pain. Two couples, two absences, two roads, taking the story further into unknown territories.

Head-On Foreign Land
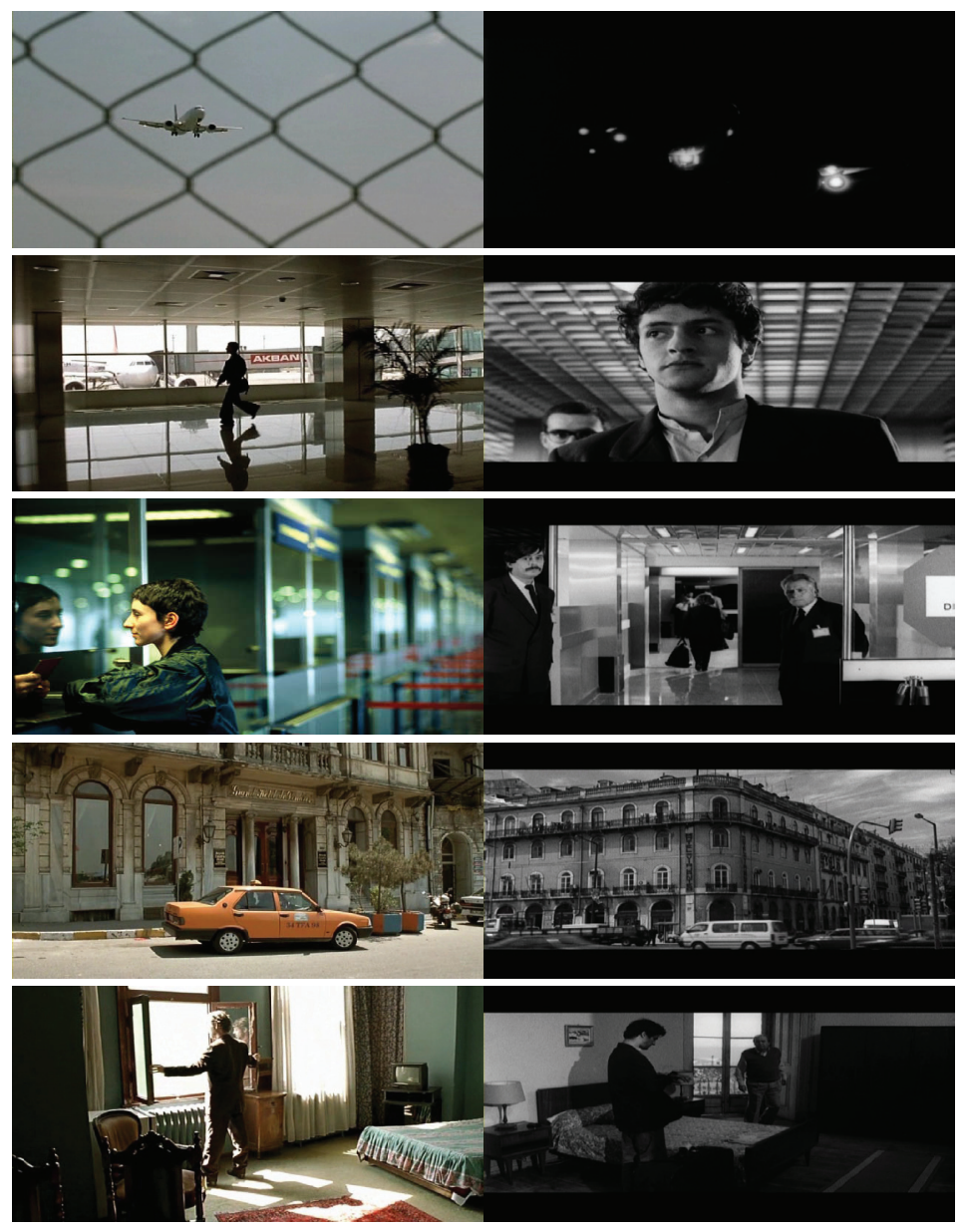


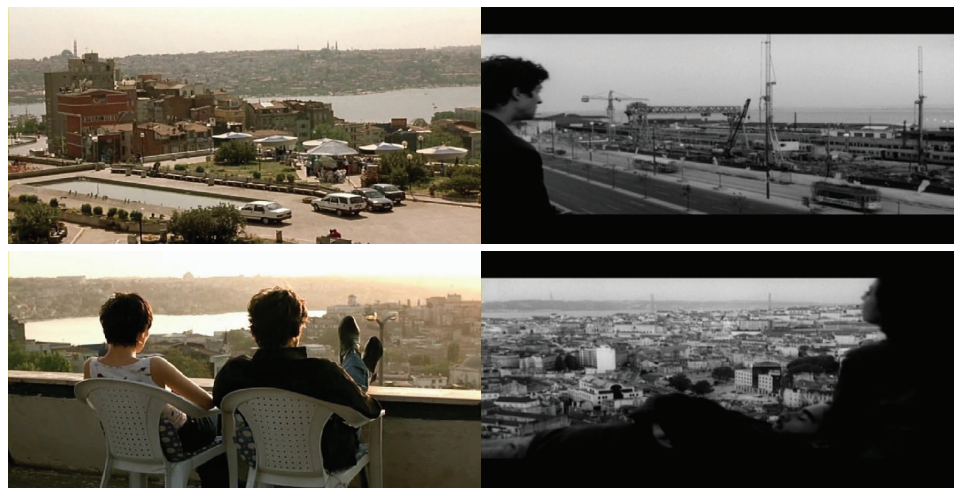

\section{Import Export}

If in Foreign Land and Head-On borders are shown prominently; in Import Export they remain inconspicuous. Here, the East and the West are posited as "two worlds that are increasingly coming to resemble each other", in Ulrich Seidl's own words (5). The Austrian director has been described as the enfant terrible of contemporary world cinema, having directed a series of films that defy categorisation while offering an inclement look into Austrian society. ${ }^{2}$ With Import Export he ventures outside Austria to present, as the title indicates, a double movement: that of Olga, a nurse from Snizhne in Eastern Ukraine, who moves to Vienna in search of a better life, leaving behind her mother and young daughter; and that of Pauli, a recently-unemployed security guard who embarks on a road trip with his stepfather through the cities of Kosice in Slovakia and Uzhgorod in Western Ukraine, installing chewing gum and pinball machines in council states. In this film the city names are made explicit through the use of subtitles, announcing each new location as the journeys progress.

Not surprisingly, the first shots of Import Export also announce immobility rather than movement: in Vienna a man repeatedly tries 
to start a motorbike, to no avail. In Snizhne, where cast and crew shot under extreme temperatures of -30 degrees, the cityscape is desolate, and Olga appears dressed in white, stumbling across the snowy path in her high-heels. If in Foreign Land bank accounts were frozen, here the whole city seems to be so, and the image of a military aircraft, which has not taken to the skies in a long time, dialogues with the motorbike which will not start in the first shot, as well as with the "big worm" wrecked in São Paulo and the shipwreck encountered by Alex and Paco.

Before Olga's arrival in Vienna, one point of contact is established between the two cities through the Ukrainian live-sex internet firm in which she decides to try her luck. Here, the voice on the other side of the computer screen speaks with an Austrian accent, and Olga replies in rudimentary German, failing to understand her client's instructions. Import Export shifts 21 times from East to West, but rather than developing in a schematic fashion it confounds expectations on a number of levels. The anticipated encounter between Olga and Pauli, for instance, never happens. She arrives in Vienna's railway station, meets her compatriot Natasha and leaves. Pauli is seen inside a station, perhaps the same one, but this is not made clear. Both characters are humiliated throughout the film, but are never depicted as victims and manage to maintain their dignity. Olga, by then employed in a geriatric hospital in Vienna as a cleaner, ends the film enjoying a good laugh with her colleagues. Pauli, in his turn, abandons his horrifying stepfather inside a hotel room in Uzhgorod, and is last seen hitchhiking alone. As in Foreign Land and Head-On, the trope of the road reappears towards the end, pointing to new directions and new journeys. Yet this road has once again a pessimistic overtone, for the film's last cut brings it back to the geriatric hospital, where a dying patient insists on repeating out loud the word "death". 

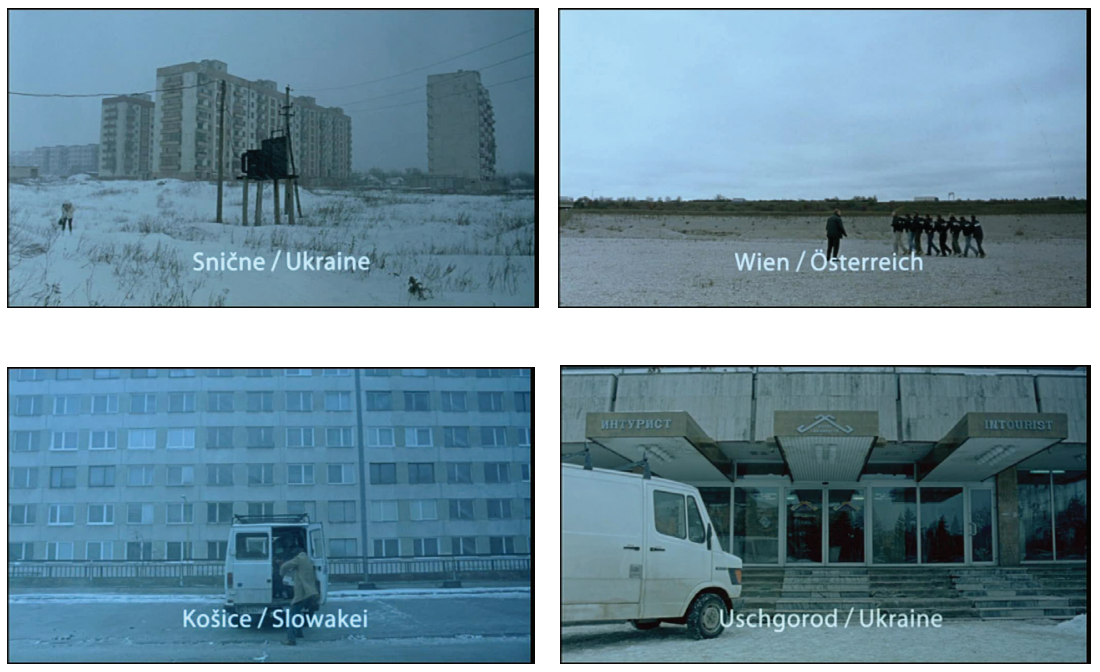

East and West in Import Export
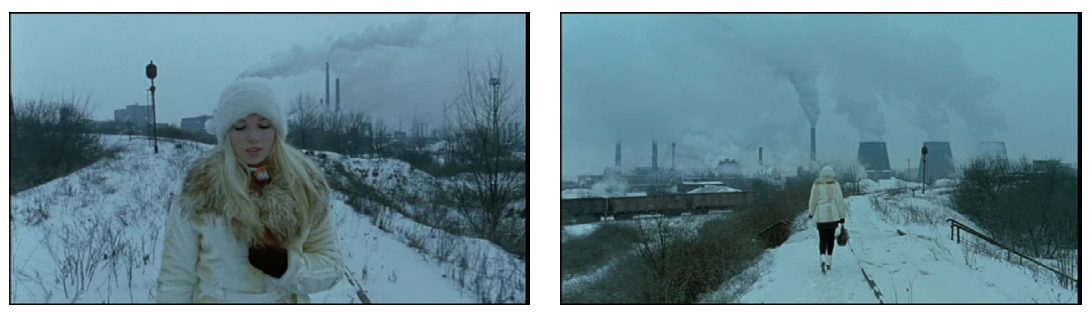

Olga walks around a snowy Snizhne
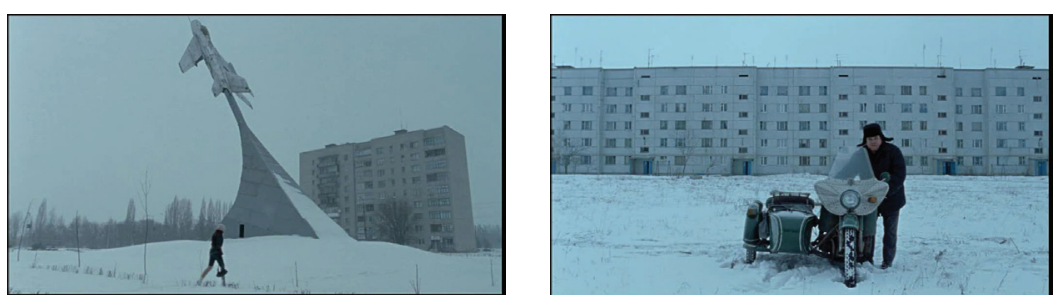

A military aircraft stuck to the

A motorbike that will not start ground 


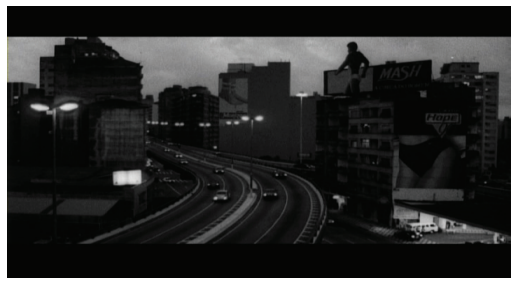

The "big worm" wrecked in the city

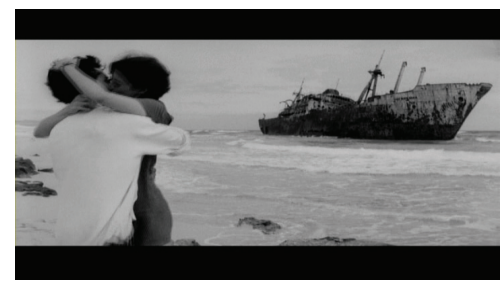

The shipwreck in Foreign Land

\section{What Time Is It There?}

Tsai Ming-liang's What Time Is It There? seems to start from where Import Export left off, that is, with a death. It opens with a long take of Miao Tian-a recurring character in Tsai's films-smoking at the kitchen-table, and then walking towards the back of the house and disappearing into the balcony. This is followed by a shot of Hsiao Kang, his son, carrying his ashes in an urn and travelling through Taipei in the back of a car. The film, dedicated to the late fathers of both Tsai and his actor Hsiao Kang, offers a reflection on travelling and time difference. Significantly, Hsiao Kang sells watches in a skywalk by Taipei Main Station. Shiang-chyi, on her way to Paris, is looking for a dual-time watch, and as it turns out becomes intent on buying the one he is wearing. He refuses to sell it because he is in mourning, and thus his watch could bring her bad luck, but eventually he concedes. This casual encounter, as well as the death of Miao Tien, are the main motifs which set the film in motion. Hsiao Kang, still in Taipei, has to deal with two absences: that of his father and that of Shiang-chyi, whose memory he keeps alive in an obsessive habit of setting clocks to the Paris time zone, trying in vain to remain close to her, or to breach the spatial lapse by adjusting Taipei to the time lapse. 
As mentioned before, the treatment of the cities from which the directors of Foreign Land and Head-On hail tends to differ from that of the destination cities, in that they receive a more fragmented and internalised depiction. A similar point could be made about Import Export, for Vienna is rarely seen in exterior shots, while Snizhne appears on more than one occasion from vantage points. It seems reasonable to suggest that this is related to the directors' point of view in relation to space, varying from the insider (in their own countries) to the outsider (in foreign countries)-thus corresponding to both a closer and a more distanced camera gaze. In What Time, however, the opposite seems to happen ${ }^{3}$ : Tsai's outsider's point-ofview does not translate into a distanced look, and Paris is deprived of a totalising view, receiving instead a more internalised treatment.

In fact, despite having been entirely shot on location, What Time has but one external scene in Paris. The director attempts to create an atmosphere of solitude and isolation, and seems uninterested in picturesque external locations. As De Bruyn writes in Positif, the French capital "was filmed without a photogram of exoticism [...] in Paris, as in Taipei, suffering and solitude resemble each other" (6). Sporting a new short haircut, just as Sibel did when moving to Istanbul, Shiang-chyi is seen inside her hotel room, in a café, in a restaurant, in the metro, making a phone call from a public telephone, but every time her disconnection from the surrounding ambience is highlighted: she is always alone; she stands still in the escalator as everyone else walks past her; she is halted by the ticket inspectors, then waits for a train which arrives at the opposite platform; she cannot understand the menu at the restaurant, and when trying to make a phone call is interrupted by a Frenchman screaming in the adjacent booth; and she finally throws up after drinking too much coffee. There is a suggestion that Shiang-chyi 
124 Cecília Mello, Urban Encounters: Stasis, Movement, Editing and ...

inhabits another time zone, preventing her to engage with the Parisian urban space.
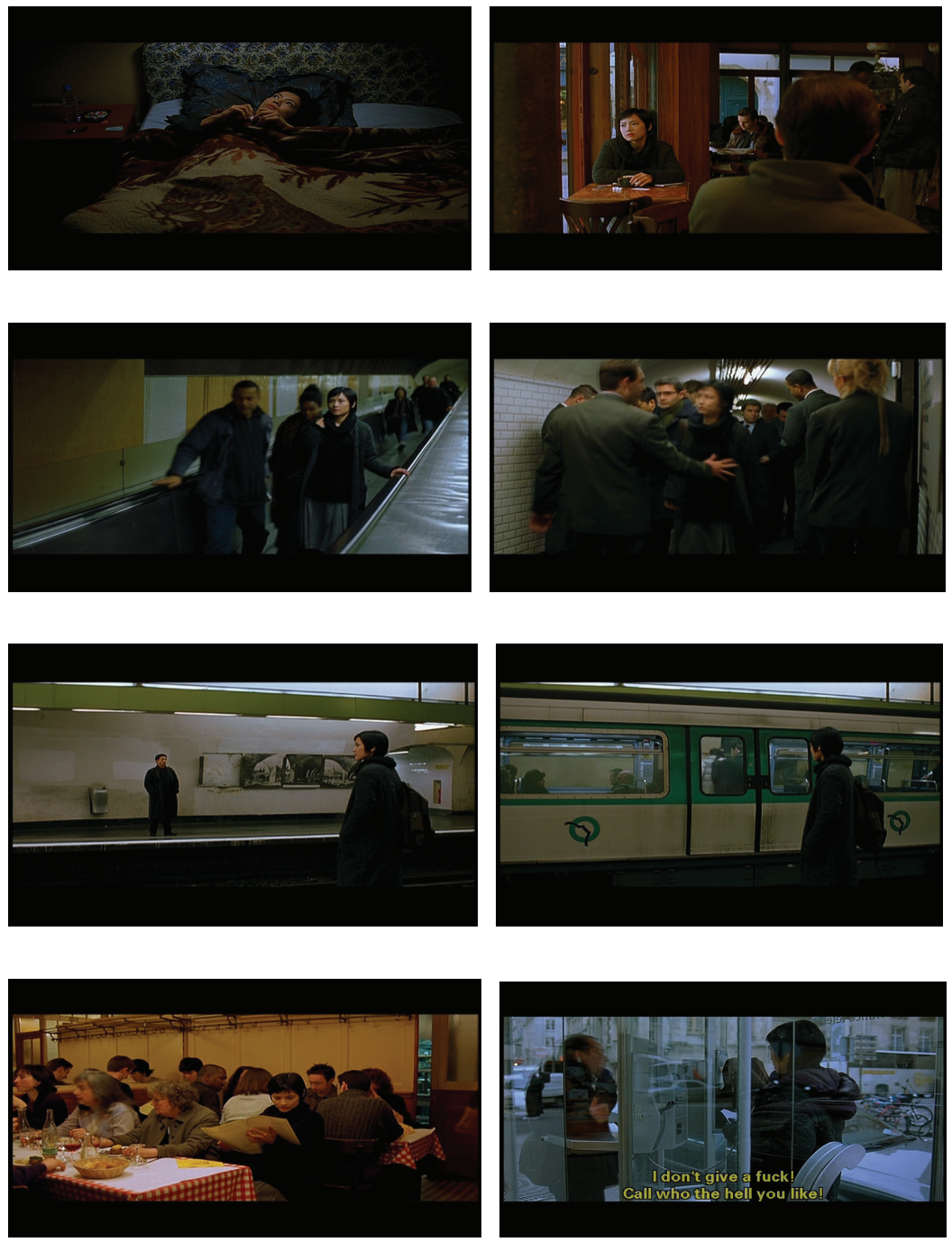

Shiang-chyi leads an out-of-tune existence in Paris 
What Time is structured on parallel editing, cutting between Taipei and Paris 24 times, totalling thirteen sequences in each city. It focuses on Shiang-chyi, Hsiao Kang and his mother, Lu Yi-ching, who spends most of her time mourning her husband's death. The film's surprising final sequence unites the reincarnation of Hsiao Kang's father and the opening to the exterior location of the Jardin the Tuileries in Paris, where Shiang-chyi sleeps in a chair as her bag floats in the fountain. The Ferris wheel, first seen reflected in the fountain and later as a backdrop to Miao Tien's ghost, suggests once again the trope of the road, only this time rather than pointing towards new trajectories it stands for a perpetual renewal, for re-incarnation and the movement between life and death and life again, in tune with the Buddhist beliefs expressed and nurtured by Lu Yi-ching throughout the film.
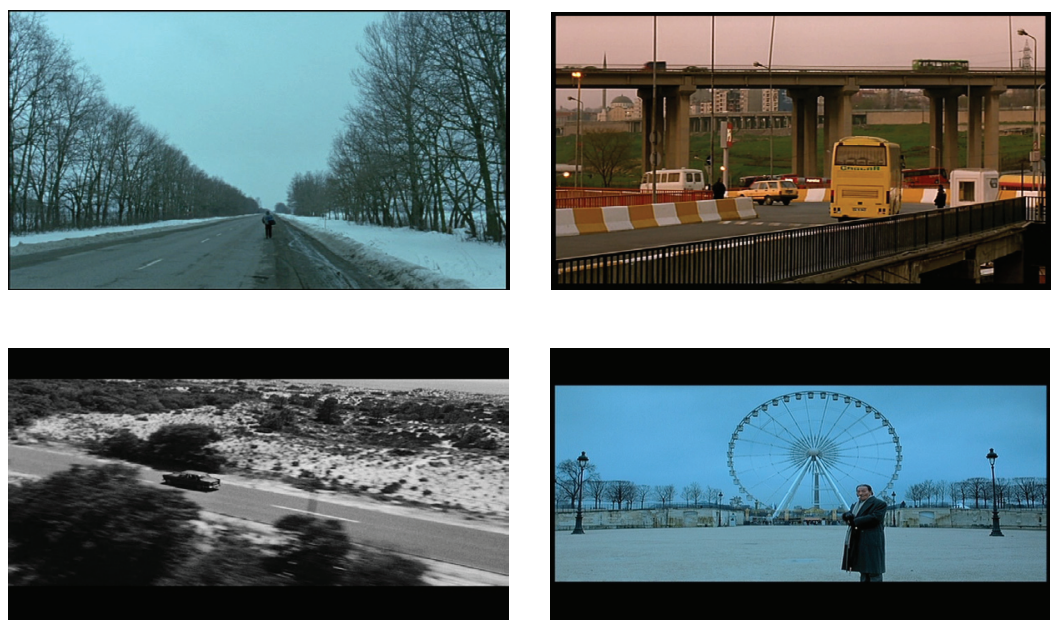

The trope of the road in Import Export, Head-On, Foreign Land and What Time Is It There? 


\section{Cities of Memories}

By reinventing the geography of Taipei and Paris, which are made to appear rather impersonal and claustrophobic, Tsai seems to be suggesting that cities can also be found internally, built from the memories and feelings of each individual experiencing urban isolation. As Italo Calvino rightly explains, "cities are an ensemble of so many things: of memories, of desires, of signs of a language; cities are places of exchange, as all history books explain, but these exchanges are not only commercial, they are exchanges of words, desires, recollections" (ix-x). If cities are spaces in flux, as Calvino suggests, cinema brings together the real city-that is, the physical space in which the films were shot, the indexical city and the internal city, and promotes its own spatiality for the communication of memories. It is a well-known fact that the flashback device is the classical mode through which to convey memory in the cinema, harking back to a past time accessed through, for instance, a dissolve. Memory's association with time is therefore highlighted, as well as its connection with the present of the one who remembers. Bertrand Russell in The Analysis of Mind describes how the memory of a past event is in fact contained, or has a causal connection, with the present:

Everything constituting a memory-belief is happening now, not in that past time to which the belief is said to refer. It is not logically necessary to the existence of a memory-belief that the event remembered should have occurred, or even that the past should have existed at all.[...] Hence the occurrences which are called knowledge of the past are logically independent of the past; they are wholly analysable into present contents, which might, theoretically, be just what they are even if no past had existed. (159-160) 
In the city films analysed in this article, the exchange happens between two cities separated by the equally classical device of parallel editing, or cross-cutting, in which temporal simultaneity is suggested against spatial disconnection, much in tune with our contemporary experience of time and space. Giuliana Bruno has described cities as "layers of sediments, the sum of every image, impression or feeling that we, as we live or traverse them, carry within ourselves. [...] In this sense, memory is especially activated in space, rather than in time" (qtd. in Broggi 23-4). In the present tense, memory's spatial dimension is highlighted, for as Edward Casey suggests the embodiment as a necessary condition of remembering points towards a place: "as embodied existence opens onto place, indeed takes place in place and nowhere else, so our memory of what we experience in place is likewise place-specific" (182). Memory is thus a point of connection between the event remembered, the person remembering it and the place of the remembered.

In What Time Is It There?, connection points are established between the two cities which keep alive the memory of Hsiao Kang and Taipei in Shiang-chyi: the dual-time watch she had bought from him is one such point, appearing ostensibly in the Paris sequences as a reminder of this connection. Moreover, if the past is brought to the present through memory, activated by a place, it is no wonder the film and the city are populated by ghosts: Shiang-chyi's hotel in Paris, for instance, seems haunted by mysterious noises coming from the room above hers; Hsiao Kang's father, having also travelled from Taipei to Paris, re-incarnates in the Tuileries; and finally Montmartre's Cemetery becomes the site of a chance encounter with none other than Jean-Pierre Léaud. Significantly, this encounter happens in the very heterotopic space in which François Truffaut is buried. And while Léaud is still alive in Paris, Truffaut's ghost-together with a 
younger version of Léaud-travels in the opposite direction towards Taipei, in one of the film's most memorable sequences. For if Shiangchyi remembers Taipei, Hsiao Kang, obsessed as he is with breaching a time difference, cannot remember Paris, for he has never seen it. He thus decides to buy a film shot in Paris, The 400 Blows (Les 400s Coups, 1959), through which he is able to fabricate a "virtual memory" of that city, in Giuliana Bruno's terms:

Cities are preeminently spaces that not only evoke memory, but fabricate it and hold it. The same thing applies to the virtual memory we fabricate through screens [...]. By putting before us framed images of virtual places and landscapes, cinema opens windows onto the world, and creates inside us, precisely as architecture does, mental and emotional maps. (qtd. in Broggi 23-4)

By positioning Hsiao Kang as a spectator of The 400 Blows, Tsai honours his beloved film, which he saw after moving from Malaysia to Taiwan in his early twenties, and through which he was also able to fabricate his own virtual memory of Paris. As Song Hwee Lim points out, "Tsai's cinephilic consumption of Truffaut's film has produced an intertextual cinema that weaves the two auteurs and their protégés in a complex web of network..." (236). This dialogue is staged firstly through the famous fairground scene, in which, as Lúcia Nagib puts it, "Truffaut stands next to Doinel inside a gyrating rotor machine, filmed in such a way as to reproduce the mechanism of the praxinoscope, a predecessor of the cinematographe". She adds that "the physical experience of the centrifugal force, which plasters participants against the rotor wall, unites character, actor and auteur in a cleverly devised fusion of film fable and real life" (World 65). This metalinguistic scene also introduces the circular motif in What 
Time Is It There?, which reappears in the final shots at the Tuileries in connection to re-incarnation. It is also related to the director's own childhood memories of embarking on a similar ride in a Kuching fairground.
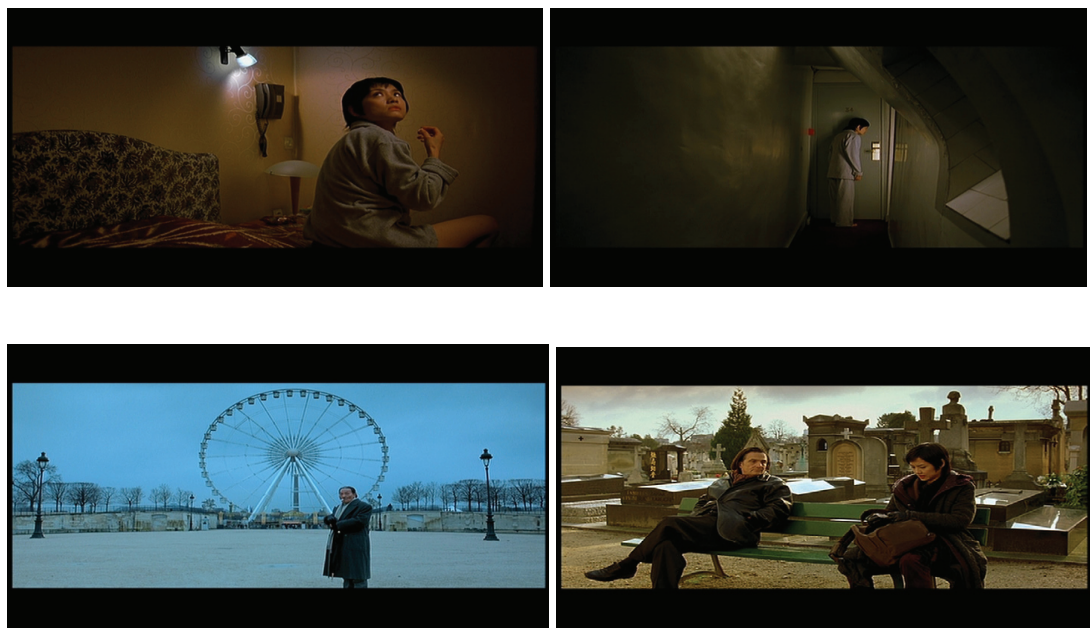

Ghosts in What Time Is It There?
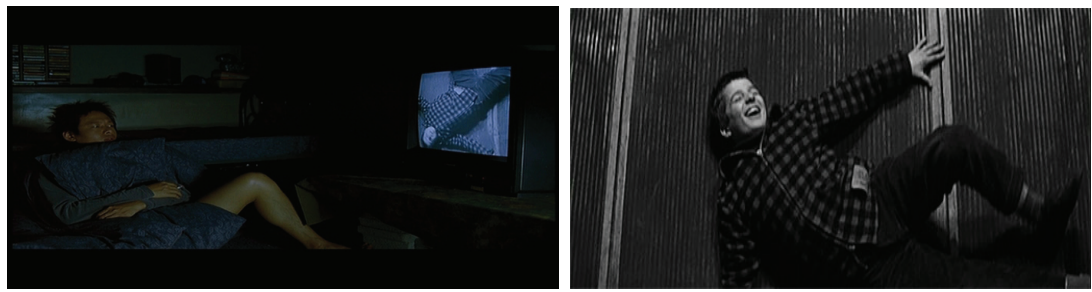

In Taipei, Hsiao-Kang fabricates a virtual memory of Paris through Truffaut's The 400 Blows

If Paris becomes a virtual memory fabricated through a screen to the longing character in Taipei, San Sebastián also remains a virtual memory to Paco in Foreign Land, fabricated by a postcard. Having 
reached Portugal but failing to reach San Sebastián, the image of the postcard functions as the only connecting point between his mother's homeland and his own. Lisbon, in its turn, is imbued with a sense of nostalgia which relates to Manuela's memories of her distant homeland. Before dying, she had told Paco how she had saved enough money to travel back to the Basque Country, to which he replied: "We cannot afford it, forget San Sebastián". "You don't understand", she says to him, "it's San Sebastián that won't leave me". The internal dimension of cities is thus made explicit by Manuela, something which Paco then fails to comprehend, but which will begin to make sense once he embarks on his journey across the sea.

Istanbul does not have a similar nostalgic function to a single character, but also appears as a postcard, only this time a live one, in the tableau which renders Head-On its Brechtian structure. The image of the city seems to hang over Cahit and Sibel's Hamburg, the sound of the music performed by the band of Romany musicians alongside Turkish actress Idil Üner invariably bleeding over the images in Germany, anticipating the cut to the postcard shot on the banks of the Golden Horn. Other instances in the film, in which Cahit, like Paco before him, rummages through pictures of his deceased wife, and Sibel's father burns her pictures following the revelation of her extra-marital affairs, as if to erase any traces of her existence, suggest yet again how images and places are containers of memories. Istanbul is here an old memory, perhaps a collective one, belonging to the characters, their families, the actors and the director himself.

Import Export, with its two-way system structure, first connects Vienna and Snizhne through the computer screen and the live sex link. It later replaces the pornographic bridge with an auditory one, which comes in the form of a song. First heard in the Ukraine, "Serdtse" /"Heart", as sung by Pyotr Leschchenko, reappears on two 
occasions in the film: once when Olga dances with one of her patients from the geriatric hospital in Vienna, and more significantly in the brief phone call she makes from the hospital to her mother and little daughter. Her memory of Snizhne emerges through the song, which she intones over the phone connecting her to both her past and her future.
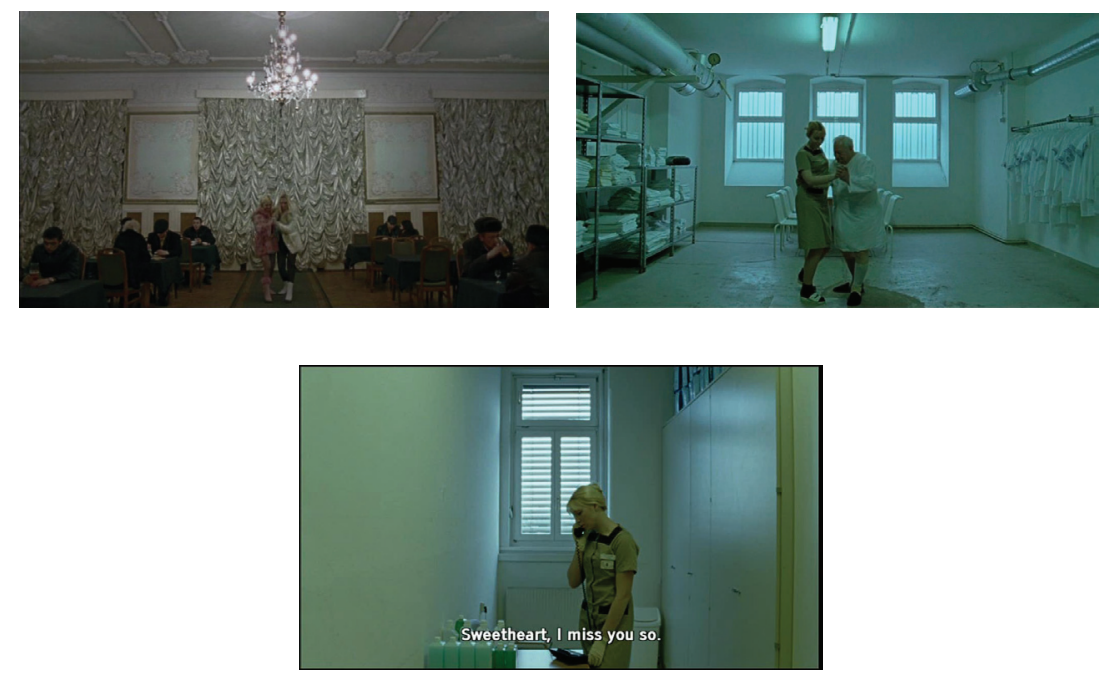

"Serdtse"/ "Heart", an auditory bridge between East and West in Import Export

\section{Conclusion}

In our era of simultaneity and interconnectedness, these four geographically distant and quite different films somehow manage to employ comparable devices in their articulation of real urban spaces. Structured upon a journey between two cities, certain motifs are both recurrent and revealing, such as the tension between movement and stasis which permeates their opening sequences, the trope of the 
road which points towards new trajectories or towards renewal in their closing sequences, and the use of a parallel editing structure. Cinema, as a travelling medium, was from the outset able to breach long distances, both through distribution/exhibition and through the editing, gluing together pieces of different spaces and different times, for different purposes. In these notable examples of contemporary cinema's travelling impulse, the editing functions as a backwards and forwards drive, producing what could be called a meaningful encounter. As well as the cuts, other points of contact between the two cities also seem to perforate space and reach to one another: a postcard, a song intoned by a mother or played by a band, a computer screen, a dual-time watch, a ghost, an actor, a film. Connections that reawaken, and fabricate, cinema's spatial memories.

\section{Acknowledgments:}

An earlier version of this article was presented as a Public Lecture at the Centre for World Cinemas, University of Leeds (March 2011). I would like to thank Prof. Lúcia Nagib and the Centre for World Cinemas for supporting my research during the time I was based at Leeds as a Visiting Fellow (January-March 2011). The research was financed by FAPESP - São Paulo Research Foundation, Brazil.

\section{Notes}

1. For an insightful analysis of the significance of this cut and of San Sebastián in Foreign Land see Lúcia Nagib’s "Back to the margins in search of the core: Foreign Land's geography of exclusion". Ed. Dina Iordanova, David Martin-Jones and Belén Vidal. Cinema at the Periphery: Industries, Narratives, Iconography. Detroit: Wayne State University, 2010.

2. See for instance Animal Love (Tierische Liebe, 1996); Models (1999); State of the Nation: Austria in Six Chapters (Zur Lage: Osterreich in sechs Kapiteln, 2002); Jesus, You Know (Jesus, Du weisst, 2003). His 2001 
feature Dog Days (Hundstage) is equally poignant.

3. Tsai Ming-liang is a Malaysian-born Chinese but has lived in Taipei for over thirty years.

\section{References}

Andrew, Dudley. "An Atlas of World Cinema." Remapping World Cinema: Identity, Culture and Politics in Film. Ed. Song Hwee Lim and Stephanie Dennison. London: Wallflower, 2005. 19-29. Print.

Berry, Chris. "What Is Transnational Cinema? Thinking from the Chinese Situation." Transnational Cinemas 1.2 (2010): 111-127. Print.

Broggi, Laura. "Atlas of Emotion: Intervista a Giuliana Bruno." Aria 1 (2005): 14-29. Print.

Bruno, Giuliana. Atlas of Emotion: Journeys in Art, Architecture and Film. New York: Verso, 2007. Print.

. "City Views: The Voyage of Film Images." The Cinematic City. Ed. David B. Clarke. London: Routledge, 1997. 46-58. Print.

Calvino, Italo. Le città invisibili. Milano: Oscar Mondadori, 2006. Print.

Casey, Edward. Remembering: A Phenomenological Study. Bloomington: Indiana University, 2000. Print.

De Bruyn, Olivier. "Et là-bas, quelle heure est-il?: Histoires de fantômes." Positif 488 (2001): 6-10. Print.

Deleuze, Gilles. Cinéma 1: L'Image-mouvement. Paris: Les Editions de Minuit, 1985. Print.

. Cinéma 2: L’Image-temps. Paris: Les Editions de Minuit, 1985. Print.

Eisenstein, Sergei. Towards a Theory of Montage: v. 2. Ed. Michael Glenny and Richard Taylor. London: I.B. Tauris, 2010. Print.

Ferreira, Carolin Overhoff. "The Limits of the Luso-Brazilian Brotherhood : Fortress Europe in the Film Foreign Land." Third Text 20.6 (2006): 733 43. Print. 
Foucault, Michel. “Of Other Spaces.” Diacritics 16 (1986): 22-7. Print.

Hallam, Julia. "Film, Space and Place: Researching a City in Film." New Review of Film and Television Studies 8.3 (2010): 277-296. Print.

Higbee, W. and S. H. Lim. "Concepts of Transnational Cinema: towards a Critical Transnationalism in Film Studies." Transnational Cinemas 1.1 (2010): 7-21. Print.

Latham, Alan, et al. Key Concepts in Urban Geography. Los Angeles: Sage, 2009. Print.

Lim, S. H. "Positioning Auteur Theory in Chinese Cinemas Studies: Intratextuality, Intertextuality and Paratextuality in the Films of Tsai Ming-liang." Journal of Chinese Cinemas 1.3 (2007): 223-245. Print.

Massey, Doreen and Karen Lury. "Making Connections." Screen 40.3 (1999): 229-238. Print.

Nagib, Lúcia. “Towards a Positive Definition of World Cinema.” Ed. Song Hwee Lim and Stephanie Dennison. Remapping World Cinema: Identity, Culture and Politics in Film. London: Wallflower, 2005. 30-37. Print.

. World Cinema and the Ethics of Realism. New York: Continuum, 2011. Print.

Nowell-Smith, Geoffrey. "Cities: Real and Imagined." Ed. Mark Shiel and Tony Fitzmaurice. Cinema and the City: Film and Urban Societies in a Global Context. Oxford: Blackwell, 2001. 99-108. Print.

Russell, Bertrand. The Analysis of Mind. London : George Allen \& Unwin, 1924. Print.

Salles, Walter and Thomas, Daniela. Foreign Land DVD Commentary, 2005.

Sassen, Saskia. The Global City: New York, London, Tokyo. Princeton: Princeton University, 2001. Print.

Seidl, Ulrich. Dossier de Presse - Import Export. Web. 21 March $2011<\mathrm{http}$ :// www.ulrichseidl.com/07Index/img/IE_Presseheft_EF.pdf>

Zhang, Y. "Comparative Film Studies, Transnational Film Studies: Interdisciplinarity, Crossmediality, and Transcultural Visuality in Chinese Cinema." Journal of Chinese Cinemas 1.1 (2007): 27-40. Print. 